\title{
ARANG AKTIF SERBUK GERGAJI KAYU SEBAGAI BAHAN ADSORBEN PADA PEMURNIAN MINYAK GORENG BEKAS
}

\section{(Activated Charcoal from Wood Sawdust as Adsorbent Material for Frying Oil Refinery)}

\author{
Oleh/By : \\ Gustan Pari $^{1)}$, Dudi Tohir ${ }^{2)}$, Mahpudin $^{3)} \&$ Januar Ferry $^{4)}$
}

\begin{abstract}
This report contains experimental study on the sawdust to produce activated charcoal with combining activation between chemical and physical. The aims of this research are 1) To study the effect of concentration of $\mathrm{H}_{3} \mathrm{PO}_{4}$ as a chemical activating agent at several percentages, 2) To study the effect of temperature and activation time on activated charcoal quality, and 3) To evaluate the use of activated charcoal to purify used frying oil. Prior to be produced activated charcoal, sawdust was carbonized in semi continuous kiln at $300^{\circ} \mathrm{C}$. Afterwards, the produced charcoal immersed in $\mathrm{H}_{3} \mathrm{PO}_{4} 5.0$ and $10.0 \%$ solution for 24 hours. Activation process was carried out in the stainless steel retort at temperature $800,850,900^{\circ} \mathrm{C}$ with activation time 30, 60 and 90 minutes, respectively. In activating process, the oxidation agent in the flowing steam was $\left(\mathrm{NH}_{4}\right)_{2} \mathrm{CO}_{3} 0.20 \%$ solution.

The results showed that good quality of activated charcoal was obtained by using $5 \%$ of $\mathrm{H}_{3} \mathrm{PO}_{4}$ solution at temperature $900^{\circ} \mathrm{C}$ with activation time 30 minute. The yield of activated charcoal at this condition was $72.71 \%$ with its properties of moisture content $4.23 \%$, volatile matter $5.84 \%$, ash content $42.53 \%$, fixed carbon $52.25 \%$, adsorptive capacity of chloroform $24.86 \%$, benzene $16.97 \%$ and adsorptive capacity of iodine $668.63 \mathrm{mg} / \mathrm{g}$. The quality of activated charcoal, especially the adsorptive capacity of iodine, has met the requirement of the American Standard. The characteristic of these activated charcoals was polar. So it can be use to adsorp pollurion which has polar characteristic like aldehyde. The quality of used frying oil increased after purifcation, as shown by the decreases in free fatty acid from 0.27 to $0.17 \%$, peroxide number decreased from 18.87 to $10.96 \mathrm{meq} \mathrm{O} 2 / \mathrm{kg}$. Meanwhile the colour of the oil became more brightness, from 13.98 to $16.02 \%$. The quality of used frying oil especially free fatty acid and peroxide number has met the requirement of Indonesian Nasional Standard.
\end{abstract}

Keywords: Sawdust, activated charcoal, iodine, frying oil, free fatty acid

\footnotetext{
ABSTRAK

${ }^{1)}$ Peneliti pada Pusat Penelitian dan Pengembangan Hasil Hutan, Bogor

${ }^{2)}$ dan ${ }^{4)}$ F-MIPA, Institut Pertanian Bogor, Bogor

${ }^{3)}$ Teknisi pada Pusat Penelitian dan Pengembangan Hasil hutan, Bogor
}

Tulisan ini mengemukakan hasil penelitian pembuatan arang aktif dari serbuk gergaji kayu dengan proses aktivasi kombinasi antara cara kimia dan fisika. Tujuan dari penelitian ini adalah untuk 
mengetahui 1) Pengaruh konsentrasi asam fosfat sebagai bahan pengaktif kimia, 2) Pengaruh suhu dan lama waktu aktivasi terhadap mutu arang aktif dan 3) Pengaruh penambahan arang aktif terhadap mutu minyak goreng bekas. Sebelum dibuat arang aktif, terlebih dahulu serbuk gergaji kayu dibuat arang dengan menggunakan tungku semi kontinyu pada suhu $300^{\circ} \mathrm{C}$. Arang yang dihasilkan selanjutnya direndam dalam larutan asam fosfat dengan konsentrasi 5,0 dan 10\% selama 24 jam. Proses aktivasi dilakukan di dalam retort yang terbuat dari besi tahan karat pada suhu $800,850,900^{\circ} \mathrm{C}$ dengan lama waktu aktivasi masing-masing 30, 60 dan 90 menit. Dalam penelitian ini digunakan larutan $\left(\mathrm{NH}_{4}\right)_{2} \mathrm{CO}_{3}$ $0,20 \%$ sebagai gas pengoksid.

Hasil penelitian menunjukkan bahwa kualitas arang aktif serbuk gergaji kayu yang terbaik adalah arang aktif yang direndam asam fosfat $5 \%$ pada suhu $900^{\circ} \mathrm{C}$ selama 30 menit. Pada proses aktivasi tersebut diperoleh rendemen arang aktif sebesar $72,71 \%$, dan arang aktif yang dihasilkan mengandung kadar air 4,23\%, kadar zat terbang 5,84\%, kadar abu 42,53\%, kadar karbon terikat 52,25\%, daya serap terhadap kloroform $24,86 \%$, benzena $16,97 \%$ dan daya serap terhadap yodium sebesar $668,63 \mathrm{mg} / \mathrm{g}$. Nilai daya serap ini memenuhi syarat Standar Amerika dan arang aktif yang dihasilkan permukaannya lebih bersifat polar sehingga dapat digunakan untuk menyerap polutan yang juga bersifat polar seperti aldehida. Kualitas minyak goreng bekas menjadi lebih baik setelah ditambahkan dengan arang aktif sebanyak 2,5\% yang ditunjukkan dengan menurunnya kandungan asam lemak bebas dan bilangan peroksida masing-masing dari $0,27 \%$ menjadi $0,17 \%$ dan dari 18,87 menjadi 10,96 meq O2/kg. Sedangkan untuk kecerahan warna mengalami peningkatan dari 13,98 menjadi 16,02\%. Mutu minyak goreng ini terutama asam lemak bebas dan bilangan perokisda memenuhi syarat minyak goreng yang ditetapkan SNI.

Kata kunci : Serbuk gergaji, arang aktif, iodin, minyak goreng, asam lemak bebas

\section{PENDAHULUAN}

Minyak goreng berfungsi sebagai media penghantar panas sehingga proses pemanasan menjadi lebih efisien dibandingkan dengan proses pemanggangan dan perebusan, karena proses penggorengan dapat meningkatkan cita rasa, kandungan gizi, daya awet, penambah rasa gurih pada makanan, dan nilai kalor. Mutu minyak goreng ditentukan dari titk asapnya, yaitu suhu pemanasan minyak sampai terbentuknya akreolin yang tidak diinginkan yang dapat menimbulkan rasa gatal pada tenggorokan karena terjadi hidrolisis molekul minyak. Makin tinggi titik asap makin baik mutu minyak goreng tersebut. Menurut Winarno (1997) titik asap suatu minyak goreng tergantung dari kadar gliserol bebas yang dikandungnya.

Menggoreng pada suhu tinggi dan minyak goreng digunakan berkali-kali akan menurunkan mutu minyak goreng yang antara lain ditunjukkan oleh warna yang makin gelap dan bau tengik, sehingga akan menurunkan mutu bahan pangan yang digoreng baik dari segi rasa, penampilan dan kesehatan. Hal ini disebabkan asam lemak tidak jenuh yang teroksidasi menghasilkan senyawa peroksida dan karbonil pada minyak goreng (Perkins. 1967).

Untuk memperpanjang umur pakai minyak goreng, maka alat dan kondisi penggorengan harus diperhatikan, sedangkan untuk minyak goreng yang telah digunakan perlu dilakukam filtrasi dengan adsorben sehingga mutu minyak dapat dipertahankan. Bahan adsorben yang dapat digunakan adalah kaolin, bentonit, zeolit, alumina dan arang aktif. Adsorben ini dapat menghilangkan sebagian asam lemak bebas, peroksida dan warna yang ditimbulkan oleh reaksi pencoklatan. 
Dalam penelitian ini dilakukan pemurnian minyak goreng bekas dengan menggunakan arang aktif dari serbuk gergaji kayu, karena menurut hasil penelitian Pari, et al. (2000) bahwa arang aktif dapat digunakan untuk menjernihkan minyak goreng kualitas II. Dipilihnya serbuk gergaji kayu sebagai bahan baku arang aktif, selain harganya murah dan potensinya cukup tinggi juga mengurangi dampak buruk ke lingkungan, berupa asap dari hasil pembakaran serbuk gergaji kayu.

\section{BAHAN DAN METODE}

\section{A. Bahan}

Bahan baku yang digunakan dalam penelitian ini adalah campuran serbuk gergaji kayu yang diperoleh dari daerah Jasinga, Jawa Barat. Bahan kimia yang digunakan diantaranya adalah $\mathrm{H}_{3} \mathrm{PO}_{4}, \mathrm{KI}, \mathrm{Na}_{2} \mathrm{~S}_{2} \mathrm{O}_{3}, \mathrm{NaOH}$, kloroform, etanol, dan air suling.

\section{B. Metode}

Serbuk gergaji kayu diarangkan pada kiln semi kontinyu. Arang yang dihasilkan direndam di dalam larutan $\mathrm{H}_{3} \mathrm{PO}_{4}$ dengan konsentrasi 5,0\% dan 10,0\% selama 24 jam. Arang hasil perendaman tersebut setelah ditiriskan, di aktivasi di dalam retort pada suhu 800, 850 dan $900^{\circ} \mathrm{C}$ dengan lama aktivasi masing-masing 30,60 dan 90 menit sambil dialirkan uap air yang mengandung $\left(\mathrm{NH}_{4}\right)_{2} \mathrm{CO}_{3} 0,2 \%$.

Sifat arang aktif yang diamati meliputi rendemen, kadar air, abu, zat terbang, karbon terikat, daya serap yodium, benzena berdasarkan standar SNI No 06-3730-1995 (Anonim, 1995) dan penetapan daya serap terhadap kloroform berdasarkan standar kualitas arang aktif menurut Departemen Kesehatan di dalam Sudradjat dan Soleh (1994).

Arang aktif yang terbaik di uji kemampuannya untuk memurnikan minyak goreng bekas dengan cara menambahkan arang aktif sebanyak 5,0\% ke dalam 50 gram minyak goreng bekas dengan waktu kontak selama 60 menit. Kualitas minyak goreng yang di analisa terdiri dari penetapan kadar asam lemak bebas, bilangan peroksida dan kecerahan minyak berdasarkan standar SNI No 01-00130-1987 (Anonim, 1987).

Untuk mengetahui pengaruh konsentrasi bahan pengaktif, suhu aktivasi dan lama aktivasi terhadap mutu arang aktif dilakukan perhitungan sidik ragam dengan menggunakan rancangan acak lengkap faktorial. Selanjutnya untuk mengetahui adanya perbedaan mutu arang aktif antara perlakuan dilakukan analisis uji beda nyata jujur (Sudjana. 1980).

\section{HASIL DAN PEMBAHASAN}

\section{A. Rendemen dan Mutu Arang Aktif}

\section{Rendemen arang aktif}

Rendemen arang aktif yang dihasilkan berkisar antara 46,52 - 97,36\% (Tabel 1). Berdasarkan perhitungan sidik ragam ternyata konsentrasi asam fosfat, suhu aktivasi dan lama waktu aktivasi dan interaksinya sangat berpengaruh terhadap rendemen yang dihasilkan, 
kecuali interaksi antara konsentrasi bahan pengaktif dengan lama waktu aktivasi (Tabel 2). Rendemen arang aktif tertinggi $(97,36 \%)$ dihasilkan oleh arang yang direndam dengan $\mathrm{H}_{3} \mathrm{PO}_{4}$ $10 \%$ dan diaktivasi pada suhu $800^{\circ} \mathrm{C}$ selama 30 menit. Rendemen arang aktif terendah $(46,52 \%)$ dihasilkan oleh arang yang direndam $\mathrm{H}_{3} \mathrm{PO}_{4} 10 \%$ dan diaktivasi pada suhu $800^{\circ} \mathrm{C}$ selama 30 menit.

Sidik regresi menunjukkan, makin lama waktu aktivasi ternyata rendemen arang aktif yang dihasilkan makin turun (Tabel 3). Demikian pula pengaruh suhu aktivasi terhadap rendemen menunjukkan pengaruh yang sama walaupun hasil perhitungan uji sidik regresinya tidak nyata (Tabel 4), yaitu makin lama waktu aktivasi maka reaksi antara atom karbon dengan zat pengoksidasi makin banyak membentuk $\mathrm{CO}, \mathrm{CO}_{2}$ dan $\mathrm{H}_{2}$, sehingga jumlah arang aktif yang terbentuk makin berkurang. Begitu juga dengan suhu aktivasi, penurunan rendemen ini dapat dijelaskan dengan konsep kinetika reaksi yang menyatakan bahwa makin tinggi suhu aktivasi maka kecepatan reaksi juga akan makin cepat sehingga jumlah atom karbon yang bereaksi makin banyak dan sebaliknya jumlah atom karbon yang tersisa makin sedikit (Hartoyo et al., 1990).

Hasil uji BNJ menunjukkan bahwa tidak semua perlakuan dan interaksinya menyebabkan perbedaan rendemen arang aktif yang nyata (Tabel 6). Sebagai contoh adalah arang yang direndam $\mathrm{H}_{3} \mathrm{PO}_{4} 5 \%$ dan diaktivasi pada suhu $800^{\circ} \mathrm{C}$ selama 90 menit (a1b1c3) sebesar $66,74 \%$ tidak menunjukkan perbedaan dengan arang yang direndam $\mathrm{H}_{3} \mathrm{PO}_{4} 10 \%$ dan diaktivasi pada suhu $900^{\circ} \mathrm{C}$ dengan waktu aktivasi selama 60 menit (a2b3c2) sebesar $64,36 \%$.

\section{Kadar air arang aktif}

Kadar air arang aktif yang dihasilkan berkisar antara 2,53 - 6,31\% (Tabel 1). Semua nilai kadar air ini memenuhi persyaratan Standar Indonesia (SNI. 1995) karena kadar airnya tidak lebih dari 15\%. Berdasarkan perhitungan sidik ragam ternyata semua perlakuan dan interaksinya tidak berpengaruh terhadap kadar air arang aktif (Tabel 2). Arang aktif yang memiliki kadar air terendah $(2,53 \%)$ terdapat pada arang yang direndam dengan $\mathrm{H}_{3} \mathrm{PO}_{4} 5 \%$ dan diaktivasi pada suhu $850^{\circ} \mathrm{C}$ selama 60 menit dan yang tertinggi (6,31\%) dihasilkan oleh arang yang direndam $\mathrm{H}_{3} \mathrm{PO}_{4} 5 \%$ dan diaktivasi pada suhu $800^{\circ} \mathrm{C}$ selama 60 menit. Selanjutnya, sidik regresi menunjukkan, makin lama arang di aktivasi menghasilkan arang aktif yang mengandung kadar air yang makin rendah (Tabel 3) sedangkan untuk suhu aktivasi menunjukkan kecenderungan yang sebaliknya walaupun hasil perhitungan uji sidik regresinya tidak nyata (Tabel 4). Besar kecilnya kadar air ini lebih ditentukan oleh sifat higroskopis arang aktif terutama pada waktu proses pendinginan. Bila dibandingkan dengan arang aktif komersial sebesar 7,25\%, maka kadar air arang aktif yang dihasilkan memiliki nilai yang lebih rendah.

\section{Kadar zat terbang}

Kadar zat terbang arang aktif yang dihasilkan berkisar antara 4,39 - 18,1\% (Tabel 1) dan memenuhi persyaratan Standar Indonesia (SNI. 1995) karena kadar zat terbangnya tidak lebih dari $25 \%$. Dari analisa sidik ragam ternyata perlakuan yang memberikan pengaruh terhadap kadar zat terbang arang aktif adalah konsentrasi bahan pengaktif, suhu aktivasi, dan interaksi antara konsentarsi bahan pengaktif dengan lama waktu aktivasi (Tabel 2). Hasil uji regresi menunjukkan makin lama arang di aktivasi kadar zat terbang arang aktif yang dihasilkan 
Tabel 1. Kualitas arang aktif

Table 1. Activated charcoal quality

\begin{tabular}{|c|c|c|c|c|c|c|c|c|c|c|}
\hline \multirow{2}{*}{$\begin{array}{l}\text { Bahan } \\
\text { pengaktif } \\
\text { (Activator } \\
\text { agent), } \%\end{array}$} & \multirow{2}{*}{$\begin{array}{l}\text { Suhu } \\
\text { (Tempe- } \\
\text { rature), } \\
{ }^{\circ} \mathrm{C}\end{array}$} & \multirow{2}{*}{$\begin{array}{c}\text { Waktu } \\
\text { aktivasi } \\
\text { (Activa- } \\
\text { tion time) } \\
\text { minutes }\end{array}$} & \multicolumn{8}{|c|}{$\begin{array}{l}\text { Rendemen dan sifat fisika kimia arang aktif } \\
\text { (Yield and physico chemical properties of activated charcoal) }\end{array}$} \\
\hline & & & 1 & 2 & 3 & 4 & 5 & 6 & 7 & 8 \\
\hline \multirow[t]{3}{*}{$\mathrm{H}_{3} \mathrm{PO}_{4} 5 \%$} & $800^{\circ} \mathrm{C}$ & $\begin{array}{l}30 \\
60 \\
90\end{array}$ & $\begin{array}{l}77,12 \\
67,24 \\
66,74\end{array}$ & $\begin{array}{l}5,71 \\
3,81 \\
2,56\end{array}$ & $\begin{array}{l}12,03 \\
12,55 \\
11,54\end{array}$ & $\begin{array}{l}36,55 \\
39,03 \\
41,29\end{array}$ & $\begin{array}{l}51,39 \\
48,40 \\
47,16\end{array}$ & $\begin{array}{l}26,12 \\
21,64 \\
18,72\end{array}$ & $\begin{array}{c}14,24 \\
9,81 \\
12,03\end{array}$ & $\begin{array}{l}624,30 \\
521,12 \\
537,35\end{array}$ \\
\hline & $850^{\circ} \mathrm{C}$ & $\begin{array}{l}30 \\
60 \\
90\end{array}$ & $\begin{array}{l}84,46 \\
70,92 \\
58,54\end{array}$ & $\begin{array}{l}3,72 \\
2,53 \\
3,89\end{array}$ & $\begin{array}{l}4,39 \\
6,12 \\
7,39\end{array}$ & $\begin{array}{l}57,61 \\
50,52 \\
48,44\end{array}$ & $\begin{array}{l}37,99 \\
43,33 \\
44,65\end{array}$ & $\begin{array}{l}23,66 \\
21,75 \\
16,71\end{array}$ & $\begin{array}{l}14,14 \\
11,19 \\
10,81\end{array}$ & $\begin{array}{l}488,86 \\
363,59 \\
533,85\end{array}$ \\
\hline & $900^{\circ} \mathrm{C}$ & $\begin{array}{l}30 \\
60 \\
90\end{array}$ & $\begin{array}{l}72,71 \\
54,95 \\
50,44\end{array}$ & $\begin{array}{l}4,39 \\
4,37 \\
4,06\end{array}$ & $\begin{array}{l}5,21 \\
7,06 \\
7,37\end{array}$ & $\begin{array}{l}42,53 \\
50,56 \\
44,64\end{array}$ & $\begin{array}{l}52,25 \\
42,37 \\
47,96\end{array}$ & $\begin{array}{l}25,15 \\
36,68 \\
16,43\end{array}$ & $\begin{array}{l}16,97 \\
12,76 \\
9,74\end{array}$ & $\begin{array}{l}668,63 \\
571,38 \\
497,84\end{array}$ \\
\hline \multirow[t]{3}{*}{$\begin{array}{c}\mathrm{H}_{3} \mathrm{PO}_{4} \\
10 \%\end{array}$} & $800^{\circ} \mathrm{C}$ & $\begin{array}{l}30 \\
60 \\
90\end{array}$ & $\begin{array}{l}97,36 \\
84,59 \\
80,54\end{array}$ & $\begin{array}{l}3,81 \\
3,93 \\
2,86\end{array}$ & $\begin{array}{l}17,73 \\
14,38 \\
12,28\end{array}$ & $\begin{array}{l}41,75 \\
46,52 \\
52,62\end{array}$ & $\begin{array}{l}40,13 \\
39,08 \\
35,10\end{array}$ & $\begin{array}{l}13,90 \\
14,41 \\
18,20\end{array}$ & $\begin{array}{l}12,66 \\
11,55 \\
12,25\end{array}$ & $\begin{array}{l}403,89 \\
403,41 \\
553,27\end{array}$ \\
\hline & $850^{\circ} \mathrm{C}$ & $\begin{array}{l}30 \\
60 \\
90\end{array}$ & $\begin{array}{l}92,74 \\
78,09 \\
80,41\end{array}$ & $\begin{array}{l}3,23 \\
4,55 \\
4,48\end{array}$ & $\begin{array}{c}18,89 \\
12,66 \\
6,14\end{array}$ & $\begin{array}{l}42,69 \\
46,88 \\
50,32\end{array}$ & $\begin{array}{l}38,41 \\
40,83 \\
43,52\end{array}$ & $\begin{array}{l}16,76 \\
16,74 \\
21,85\end{array}$ & $\begin{array}{l}12,12 \\
13,02 \\
15,56\end{array}$ & $\begin{array}{l}492,32 \\
440,72 \\
457,05\end{array}$ \\
\hline & $900^{\circ} \mathrm{C}$ & $\begin{array}{l}30 \\
60 \\
90\end{array}$ & $\begin{array}{l}72,78 \\
64,36 \\
46,51\end{array}$ & $\begin{array}{l}3,32 \\
3,27 \\
3,72\end{array}$ & $\begin{array}{l}18,04 \\
13,52 \\
15,24\end{array}$ & $\begin{array}{l}44,15 \\
43,60 \\
43,90\end{array}$ & $\begin{array}{l}37,79 \\
42,95 \\
40,84\end{array}$ & $\begin{array}{l}13,77 \\
15,66 \\
13,71\end{array}$ & $\begin{array}{l}11,31 \\
12,95 \\
10,70\end{array}$ & $\begin{array}{l}496,15 \\
492,33 \\
438,29\end{array}$ \\
\hline
\end{tabular}

Keterangan (Remarks) : $1=$ Rendemen (Yield), \%; $2=$ Kadar air (Moisture content), \%; $3=$ Kadar zat terbang (Volatile matter), $\% ; 4=\mathrm{Kadar}$ abu $($ Ash content), $\% ; 5=$ Kadar karbon terikat (Fixed carbon), $\% ; 6=$ Daya serap $\mathrm{CHCl}_{3}\left(\right.$ Adsorptive capacity of $\left.\mathrm{CHCl}_{3}\right), \% ; 7=$ Daya serap benzena (Adsorptive capacity of benzene), $\% ; 8=$ Daya serap yodium (Adsorptive capacity of iodine), $\mathrm{mg} / \mathrm{g}$ 
Tabel 2. Ringkasan sidik ragam kualitas arang aktif Table 2. Summary for analysis of variance on properties of activated charcoal

\begin{tabular}{|c|c|c|c|c|}
\hline No. & $\begin{array}{c}\text { Sifat } \\
\text { (Properties) }\end{array}$ & $\begin{array}{l}\text { Perlakuan } \\
\text { (Treatment) }\end{array}$ & $\begin{array}{l}\text { Kuadrat tengah } \\
\text { (Mean square) }\end{array}$ & $\begin{array}{c}\text { F-hitung } \\
\text { (F-calculated })\end{array}$ \\
\hline 1 & 2 & 3 & 4 & 5 \\
\hline 1. & $\begin{array}{l}\text { Rendemen } \\
(\text { Yield), } \%\end{array}$ & $\begin{array}{l}\mathrm{A} \\
\mathrm{B} \\
\mathrm{C} \\
\mathrm{AB} \\
\mathrm{AC} \\
\mathrm{BC} \\
\mathrm{ABC}\end{array}$ & $\begin{array}{r}987,42 \\
1292,80 \\
1127,53 \\
183,87 \\
1,72 \\
34,12 \\
61,26\end{array}$ & $\begin{array}{c}1857,44^{* *} \\
2436,48^{* *} \\
2121,01^{* *} \\
345,88^{* *} \\
3,23 \\
64,18^{* *} \\
115,24 * *\end{array}$ \\
\hline 2. & $\begin{array}{l}\text { Kadar air } \\
\text { (Moisture content), \% }\end{array}$ & $\begin{array}{l}\mathrm{A} \\
\mathrm{B} \\
\mathrm{C} \\
\mathrm{AB} \\
\mathrm{AC} \\
\mathrm{BC} \\
\mathrm{ABC}\end{array}$ & $\begin{array}{l}0,01 \\
2,94 \\
3,62 \\
1,27 \\
0,43 \\
5,24 \\
2,36\end{array}$ & $\begin{array}{l}0,01 \\
1,67 \\
2,06 \\
0,72 \\
0,25 \\
2,97 \\
1,34\end{array}$ \\
\hline 3. & $\begin{array}{l}\text { Kadar abu } \\
(\text { Ash content }), \%\end{array}$ & $\begin{array}{l}\mathrm{A} \\
\mathrm{B} \\
\mathrm{C} \\
\mathrm{AB} \\
\mathrm{AC} \\
\mathrm{BC} \\
\mathrm{ABC}\end{array}$ & $\begin{array}{r}0,17 \\
131,40 \\
22,82 \\
148,53 \\
38,31 \\
27,72 \\
32,09\end{array}$ & $\begin{array}{c}0,09 \\
69,93^{* *} \\
12,14^{* *} \\
79,04^{* *} \\
20,39^{* *} \\
14,75^{* *} \\
17,08^{* *}\end{array}$ \\
\hline 4. & $\begin{array}{l}\text { Kadar zat terbang } \\
\text { (Volatile matter), \% }\end{array}$ & $\begin{array}{l}\mathrm{A} \\
\mathrm{B} \\
\mathrm{C} \\
\mathrm{AB} \\
\mathrm{AC} \\
\mathrm{BC} \\
\mathrm{ABC}\end{array}$ & $\begin{array}{r}331,05 \\
53,25 \\
21,24 \\
26,25 \\
63,78 \\
7,63 \\
9,41 \\
\end{array}$ & $\begin{array}{c}54,00^{* *} \\
8,69 * \\
3,47 \\
4,28 \\
10,41 * \\
1,25 \\
1,53 \\
\end{array}$ \\
\hline 5. & $\begin{array}{l}\text { Kadar karbon terikat } \\
\text { (Fixed carbon), \% }\end{array}$ & $\begin{array}{l}\mathrm{A} \\
\mathrm{B} \\
\mathrm{C} \\
\mathrm{AB} \\
\mathrm{AC} \\
\mathrm{BC} \\
\mathrm{ABC}\end{array}$ & $\begin{array}{r}359,01 \\
25,09 \\
0,44 \\
73,79 \\
15,56 \\
30,14 \\
22,60\end{array}$ & $\begin{array}{c}171,24^{* *} \\
11,97^{* *} \\
0,21 \\
35,20^{* *} \\
7,42^{*} \\
7,42^{*} \\
10,78^{*}\end{array}$ \\
\hline
\end{tabular}


Tabel 2. Lanjutan (Continued)

\begin{tabular}{|c|l|l|r|r|}
\hline 6. & Daya serap yodium & $\mathrm{A}$ & 42881 & $153,73^{* *}$ \\
& (Adsorptive capacity of & $\mathrm{B}$ & 13615 & $48,81^{* *}$ \\
& iodine), mg/g & $\mathrm{C}$ & 12783 & $45,83^{* *}$ \\
& & $\mathrm{AB}$ & 11145 & $39,96^{* *}$ \\
& & $\mathrm{AC}$ & 7567 & $27,13^{* *}$ \\
& & $\mathrm{BC}$ & 9667 & $34,66^{* *}$ \\
\hline 7. & Daya serap benzena & $\mathrm{ABC}$ & 7738 & $27,74^{* *}$ \\
\hline & (Adsorptive capacity of & $\mathrm{A}$ & 0,02 & 0,02 \\
& benzene), mg/g & $\mathrm{B}$ & 1,54 & 1,00 \\
& & $\mathrm{C}$ & 11,68 & $7,52^{*}$ \\
& & $\mathrm{AB}$ & 6,90 & 4,44 \\
& & $\mathrm{AC}$ & 22,44 & $14,44^{* *}$ \\
& & $\mathrm{BC}$ & 6,72 & 4,32 \\
& & $\mathrm{ABC}$ & 22,46 & 1,59 \\
\hline & Daya serap kloroform & $\mathrm{A}$ & 208,71 & $150,95^{* *}$ \\
& (Adsorptive capacity of & $\mathrm{B}$ & 18,70 & $13,53^{* *}$ \\
& chloroform), mg/g & $\mathrm{C}$ & 16,42 & $11,86^{*}$ \\
& & $\mathrm{AB}$ & 15,29 & $11,06^{*}$ \\
& & $\mathrm{AC}$ & 86,65 & $62,67^{* *}$ \\
& & $\mathrm{BC}$ & 3,53 & 2,56 \\
& & $\mathrm{ABC}$ & 6,91 & $5,00^{*}$ \\
\hline
\end{tabular}

Keterangan (Remarks): $\mathrm{A}=\mathrm{H}_{3} \mathrm{PO}_{4} ; \mathrm{B}=$ Suhu aktivasi (Activation temperature); $\mathrm{C}=$ Waktu aktivasi (Activation time); $\mathrm{AB}=$ Interaksi antara $\mathrm{H}_{3} \mathrm{PO}_{4}$ dengan suhu aktivasi (Interaction between $\mathrm{H}_{3} \mathrm{PO}_{4}$ and activation temperature); $\mathrm{AC}=$ Interaksi antara $\mathrm{H}_{3} \mathrm{PO}_{4}$ dengan waktu aktivasi (Interaction between $\mathrm{H}_{3} \mathrm{PO}_{4}$ and activation time); $\mathrm{BC}=$ Interaklsi antara suhu dengan waktu aktivasi (Interaction between temperature and activation time); $\mathrm{ABC}=$ Interaksi antara $\mathrm{H}_{3} \mathrm{PO}_{4}$, suhu dan waktu aktivasi (Interaction between $\mathrm{H}_{3} \mathrm{PO}_{4}$, temperature and activation time); ** = Sangat nyata (Highly significant); * = Nyata (Significant)

makin meningkat (Tabel 3). Kenaikan kadar zat terbang ini menunjukkan adanya gugus $\mathrm{OH}$ dan H yang menempel pada permukaan arang aktif selama proses aktivasi (Pari. 2004), sedangkan untuk suhu aktivasi menunjukkan kecenderungan yang makin menurun (Tabel 4). Penurunan kadar zat terbang ini menunjukkan adanya reaksi antara atom karbon dengan uap air membentuk senyawa non karbon yang menguap seperti $\mathrm{CO}, \mathrm{CO}_{2}, \mathrm{CH}_{4}$ dan $\mathrm{H}_{2}$ pada waktu proses aktivasi. Bila dibandingkan dengan arang aktif komersial sebesar 10,05\% maka kadar zat terbang yang dihasilkan memiliki nilai yang lebih rendah.

Hasil uji BNJ menunjukkan bahwa tidak semua perlakuan dan interaksinya menyebabkan perbedaan kadar zat terbang yang dikandung arang aktif (Tabel 6). Sebagai contoh adalah arang yang direndam $\mathrm{H}_{3} \mathrm{PO}_{4} 5 \%$ dan diaktivasi selama 90 menit (a1c3) sebesar 9,10\% tidak menunjukkan perbedaan dengan arang yang direndam $\mathrm{H}_{3} \mathrm{PO}_{4} 5 \%$ dan diaktivasi selama 60 menit (a1c2) sebesar 8,58\%.

4. Kadar karbon terikat

Kadar karbon terikat arang aktif yang dihasilkan berkisar antara 35,10-52,25\% (Tabel 1). Perlakuan aktivasi yang menggunakan bahan kimia sebagai bahan pengaktif, kadar karbon 
Table 3. Persamaan regresi hubungan antara waktu aktivasi (X2) terhadap sifat arang aktif $(\mathrm{Y})$

Table 3. Regression equation for a relationship between activation time (X2) and activated charcoal properties $(y)$

\begin{tabular}{|l|c|c|c|}
\hline \multicolumn{1}{|c|}{ Sifat (Properties) } & Regresi (Regression) & $\begin{array}{c}\text { Koefisien korelasi } \\
\text { (Coeficient correlation) }\end{array}$ & $\begin{array}{c}\text { F-hitung } \\
(\text { F-calc })\end{array}$ \\
\hline Rendemen (Yield), \% & $\mathrm{Y}=91,24-0,32 \mathrm{X} 2$ & $-0,9801$ & $24,1697^{* *}$ \\
\hline $\begin{array}{l}\text { Kadar air } \\
\text { (Moisture content), \% }\end{array}$ & $\mathrm{Y}=4,21-0,01 \mathrm{X} 2$ & $-0,9851$ & $18,0001^{* *}$ \\
\hline $\begin{array}{l}\text { Kadar abu } \\
\text { (Ash content), \% }\end{array}$ & $\mathrm{Y}=43,11+0,04 \mathrm{X} 2$ & 0,9610 & $12,9284^{* *}$ \\
\hline $\begin{array}{l}\text { Kadar zat terbang } \\
\text { (Volatile matter), \% }\end{array}$ & $\mathrm{Y}=13,99+0,05 \mathrm{X} 2$ & 0,9910 & $30,4958^{* *}$ \\
\hline $\begin{array}{l}\text { Kadar karbon terikat } \\
\text { (Fixed carbon), \% }\end{array}$ & $\mathrm{Y}=42,77+0,003 \mathrm{X} 2$ \\
\hline $\begin{array}{l}\text { Daya serap yodium } \\
\text { (Adsorptive capacity of } \\
\text { iodine), mg/g }\end{array}$ & $\mathrm{Y}=525,2-0,43 \mathrm{X} 2$ & 0,6155 & 0,0001 \\
\hline $\begin{array}{l}\text { Daya serap benzena } \\
\text { (Adsorptive capacity of } \\
\text { benzene), \% }\end{array}$ & $\mathrm{Y}=14,16-0,03 \mathrm{X} 2$ & $-0,4085$ & 0,2001 \\
\hline $\begin{array}{l}\text { Daya serap CHCl } \\
\text { (Adsorptive capacity of } \\
\text { CHCl }), \%\end{array}$ & $\mathrm{Y}=21,83-0,04 \mathrm{X} 1$ & $-0,6377$ & 0,6805 \\
\hline
\end{tabular}

Keterangan (Remarks): ** = Sangat nyata (Highly significant), * = Nyata (Significant)

terikatnya tidak ada yang memenuhi persyaratan Standar Indonesia (SNI. 1995) karena kadar karbon terikatnya kurang dari 65\%. Analisa sidik ragam (Tabel 2) menunjukkan bahwa konsentrasi asam fosfat, suhu aktivasi dan interaksinya berpengaruh terhadap kadar karbon terikat arang aktif yang dihasilkan, sedangkan perlakuan waktu aktivasi tidak berpengaruh terhadap kadar karbon terikat arang aktif. Kadar karbon terikat terendah (35,10\%) terdapat pada arang yang direndam $\mathrm{H}_{3} \mathrm{PO}_{4} 10 \%$ dan diaktivasi pada suhu $800^{\circ} \mathrm{C}$ selama 90 menit dan yang tertinggi $(52,25 \%)$ dihasilkan oleh arang yang direndam $\mathrm{H}_{3} \mathrm{PO}_{4} 5 \%$ dan diaktivasi pada suhu $900^{\circ} \mathrm{C}$ selama 30 menit. Walaupun sidik regresi tidak menunjukkan hubungan yang nyata antara suhu dan lama aktivasi terhadap kadar karbon terikat arang aktif, tetapi terdapat kecenderungan kadar karbon yang dihasilkan makin naik (Tabel 3 dan 4). Tinggi rendahnya kadar karbon terikat yang dihasilkan selain dipengaruhi oleh tinggi rendahnya kadar abu dan zat terbang juga dipengaruhi oleh kandungan selulosa dan lignin yang dapat dikonversi menjadi atom karbon (Pari. 2004). Bila dibandingkan dengan arang aktif komersial sebesar 79,50\% maka kadar karbon terikat arang aktif yang dihasilkan memiliki nilai yang lebih rendah.

Hasil uji BNJ menunjukkan bahwa tidak semua perlakuan dan interaksinya menyebabkan perbedaan kadar karbon terikat arang aktif yang nyata (Tabel 6). Sebagai 
contoh adalah arang aktif yang dibuat dari arang yang direndam $\mathrm{H}_{3} \mathrm{PO}_{4} 5 \%$ dan diaktivasi pada suhu $900^{\circ} \mathrm{C}$ selama 60 menit (a1b3c2) mengandung kadar karbon terikat (42,37\%) yang tidak berbeda dengan kadar karbon terikat arang aktif $(43,52 \%)$ yang dibuat dari arang yang direndam $\mathrm{H}_{3} \mathrm{PO}_{4} 10 \%$ dan diaktivasi pada suhu $850^{\circ} \mathrm{C}$ dengan selama 90 menit (a2b2c3).

Table 4. Persamaan regresi hubungan antara suhu aktivasi (X1) terhadap sifat arang aktif (Y)

Table 4. Regression equation for arelationship between activation temperature (X1) and activated charcoal properties $(Y)$

\begin{tabular}{|l|c|c|c|}
\hline \multicolumn{1}{|c|}{ Sifat (Properties) } & Regresi (Regression) & $\begin{array}{c}\text { Koefisien korelasi } \\
\text { (Coeficient orrelation) }\end{array}$ & $\begin{array}{c}\text { F-hitung } \\
(\text { F-calc })\end{array}$ \\
\hline Rendemen (Yield), \% & $\mathrm{Y}=230,6-0,18 \mathrm{X} 1$ & $-0,8979$ & 4,1654 \\
\hline $\begin{array}{l}\text { Kadar air } \\
\text { (Moisture content), \% }\end{array}$ & $\mathrm{Y}=3,19+0,001 \mathrm{X} 1$ & 0,5806 & 0,5052 \\
\hline $\begin{array}{l}\text { Kadar abu } \\
\text { (Ash content), \% }\end{array}$ & $\mathrm{Y}=29,08+0,02 \mathrm{X} 1$ & 0,2904 & 0,0919 \\
\hline $\begin{array}{l}\text { Kadar zat terbang } \\
\text { (Volatile matter), \% }\end{array}$ & $\mathrm{Y}=31,23-0,02 \mathrm{X} 1$ & 0,5659 & 0,4560 \\
\hline $\begin{array}{l}\text { Kadar karbon terikat } \\
\text { (Fixed carbon), \% }\end{array}$ & $\mathrm{Y}=38,91+0,005 \mathrm{X} 1$ & 0,1742 & 0,0326 \\
\hline $\begin{array}{l}\text { Daya serap yodium } \\
\text { (Adsorptive capacity of } \\
\text { iodine), mg/g }\end{array}$ & $\mathrm{Y}=327,4+0,20 \mathrm{X} 1$ & 0,3051 & 0,1026 \\
\hline $\begin{array}{l}\text { Daya serap benzena } \\
\text { (Adsorptive capacity of } \\
\text { benzene), \% }\end{array}$ & $\mathrm{Y}=9,79+0,003 \mathrm{X} 1$ & 0,4291 & 0,2254 \\
\hline $\begin{array}{l}\text { Daya serap CHCl } \\
\text { (Adsorptive capacity of } \\
\text { CHCl3), \% }\end{array}$ & $\mathrm{Y}=7,64+0,01 \mathrm{X} 1$ & 0,9994 & $918,72^{* *}$ \\
\hline
\end{tabular}

Keterangan (Remarks): ** = Sangat nyata (Highly significant)

5. Daya serap arang aktif terhadap yodium

Daya serap arang aktif terhadap yodium yang dihasilkan berkisar antara 363,59-668,63 $\mathrm{mg} / \mathrm{g}$ (Tabel 1) dan daya serap arang aktif tersebut tidak memenuhi persyaratan Standar Indonesia (SNI. 1995) karena daya serapnya kurang dari $750 \mathrm{mg} / \mathrm{g}$. Namun bila dibandingkan dengan Standar Amerika (AWWA. 1978) sebagian besar arang aktif yang diteliti memenuhi standar, kecuali arang aktif yang direndam asam fosfat $5 \%$, suhu $850^{\circ} \mathrm{C}$ selama 60 menit dan arang aktif yang direndam asam fosfat $10 \%$, suhu $800^{\circ} \mathrm{C}, 850^{\circ} \mathrm{C}$ dan suhu $900^{\circ} \mathrm{C}$ selama 30 , 60 menit dan 30, 60 dan 90 menit serta 60 dan 90 menit karena daya serapnya kurang dari 500 $\mathrm{mg} / \mathrm{g}$. Analisa sidik ragam (Tabel 2) menunjukkan bahwa konsentrasi asam fosfat, suhu dan lama waktu aktivasi serta interaksinya sangat berpengaruh terhadap daya serap yodium. Daya serap yodium terendah $(363,59 \mathrm{mg} / \mathrm{g})$ terdapat pada arang yang direndam $\mathrm{H}_{3} \mathrm{PO}_{4} 5 \%$ dan diaktivasi pada suhu $850^{\circ} \mathrm{C}$ selama 60 menit dan daya serap tertinggi $(668,63 \mathrm{mg} / \mathrm{g})$ dihasilkan oleh arang yang direndam H3PO4 5\% dan diaktivasi pada suhu $900^{\circ} \mathrm{C}$ selama 30 menit. 
Walaupun sidik regresi menunjukkan tidak ada hubungan yang nyata untuk suhu dan lama aktivasi terhadap daya serap arang aktif terhadap yodium, tetapi terdapat kecenderungan daya serapnya makin naik (Tabel 3 dan 4). Kenaikan ini menggambarkan struktur mikropori arang aktif yang terbentuk terutama yang berukuran 10 Angstrom makin banyak. Bila dibandingkan dengan arang aktif komersial sebesar $800,11 \mathrm{mg} / \mathrm{g}$ maka daya serap terhadap yodium yang dihasilkan memiliki nilai yang lebih rendah.

Hasil uji BNJ menunjukkan bahwa tidak semua perlakuan dan interaksinya menyebabkan perbedaan daya serap arang aktif terhadap yodium yang nyata (Tabel 6). Sebagai contoh adalah arang yang direndam $\mathrm{H}_{3} \mathrm{PO}_{4} 5 \%$ dan diaktivasi pada suhu $900^{\circ} \mathrm{C}$ selama 60 menit (a1b1c3) sebesar 537,35 mg/g tidak menunjukkan perbedaan dengan arang yang direndam $\mathrm{H}_{3} \mathrm{PO}_{4} 10 \%$ dan diaktivasi pada suhu $800^{\circ} \mathrm{C}$ selama 90 menit (a2b1c3) sebesar $553,27 \mathrm{mg} / \mathrm{g}$.

\section{Daya serap arang aktif terhadap benzena}

Daya serap arang aktif terhadap benzena yang dihasilkan berkisar antara 9,74 - 16,97\% (Tabel 1) dan tidak ada yang memenuhi persyaratan Standar Indonesia karena daya serapnya kurang dari $25 \%$ (SNI, 1995). Berdasarkan analisis sidik ragam ternyata yang berpengaruh terhadap daya serap benzena hanya waktu aktivasi dan interaksinya dengan konsentrasi bahan pengaktif (Tabel 2). Daya serap benzena terendah (9,74\%) terdapat pada arang aktif yang dibuat dari arang serbuk gergaji yang direndam $\mathrm{H}_{3} \mathrm{PO}_{4} 5 \%$ dan diaktivasi pada suhu $900^{\circ} \mathrm{C}$ selama 90 menit, dan daya serap yang tertinggi (16,97\%) dihasilkan oleh arang yang direndam $\mathrm{H}_{3} \mathrm{PO}_{4} 5 \%$ dan diaktivasi pada suhu $900^{\circ} \mathrm{C}$ selama 30 menit. Walaupun hasil uji regresi menunjukkan terdapat kecenderungan makin tinggi suhu dan waktu aktivasi, daya serap benzenanya makin naik (Tabel 3 dan 4). Kenaikan daya serap ini menggambarkan struktur mikropori arang aktif yang terbentuk terutama yang berukuran 6 Angstrom makin banyak. Bila dibandingkan dengan daya serap arang aktif terhadap benzena komersial sebesar 25,50\% maka daya serap arang aktif terhadap benzena yang dihasilkan memiliki nilai yang lebih rendah.

Hasil uji BNJ menunjukkan bahwa tidak semua perlakuan dan interaksinya menyebabkan perbedaan kadar zat terbang arang aktif yang nyata (Tabel 6). Sebagai contoh adalah arang yang direndam $\mathrm{H}_{3} \mathrm{PO}_{4} 5 \%$ dan diaktivasi selama 60 menit (a1c2) sebesar 11,26\% tidak menunjukkan perbedaan dengan arang yang direndam $\mathrm{H}_{3} \mathrm{PO}_{4} 10 \%$ dan diaktivasi selama 30 menit (a2c1) sebesar 12,04\%.

\section{Daya serap arang aktif terhadap kloroform}

Daya serap arang aktif terhadap kloroform yang dihasilkan berkisar antara 13,71 36,68\% (Tabel 1). Semua daya serap kloroform ini tidak ada yang memenuhi persyaratan yang dikeluarkan oleh Departemen Kesehatan di dalam Sudradjat dan Soleh (1994) karena daya serapnya kurang dari 40\%. Dari analisis sidik ragam ternyata semua perlakuan dan interaksinya berpengaruh terhadap daya serap kloroform, kecuali interaksi antara waktu aktivasi dan suhu aktivasi (Tabel 2). Daya serap kloroform terendah $(13,71 \%)$ terdapat pada arang yang direndam $\mathrm{H}_{3} \mathrm{PO}_{4} 10 \%$ dan diaktivasi pada suhu $900^{\circ} \mathrm{C}$ selama 90 menit dan yang tertinggi $(36,68 \%)$ dihasilkan oleh arang yang direndam $\mathrm{H}_{3} \mathrm{PO}_{4} 5 \%$ dan diaktivasi pada suhu $900^{\circ} \mathrm{C}$ selama 60 menit. Hasil uji regresi menunjukkan makin tinggi suhu aktivasi makin naik 
daya serap arang aktif terhadap $\mathrm{CHCl}_{3}$ (Tabel 4) begitu juga dengan lama waktu aktivasi menunjukkan kecenderungan yang sama walaupun hasil perhitungan uji sidik regresinya tidak nyata (Tabel 3). Kenaikan daya serap ini menggambarkan permukaan arang aktif makin bersifat polar sehingga dapat digunakan untuk menyerap polutan atau senyawa yang bersifat polar seperti aldehida dan alkohol. Bila dibandingkan dengan arang aktif komersial $(48,10 \%)$ maka daya serap arang aktif yang dihasilkan memiliki nilai yang lebih rendah.

Hasil uji BNJ menunjukkan bahwa tidak semua perlakuan dan interaksinya menyebabkan perbedaan daya serap arang aktif terhadap kloroform yang nyata (Tabel 6). Sebagai contoh adalah arang yang direndam $\mathrm{H}_{3} \mathrm{PO}_{4} 5 \%$ dan diaktivasi pada suhu $850^{\circ} \mathrm{C}$ selama 90 menit (a1b2c3) sebesar 16,717\% tidak menunjukkan perbedaan dengan arang yang direndam $\mathrm{H}_{3} \mathrm{PO}_{4} 10 \%$ dan diaktivasi pada suhu $850^{\circ} \mathrm{C}$ selama 30 menit (a2b2c1) sebesar $16,76 \%$.

\section{B. Kondisi terbaik pembuatan arang aktif untuk penjernih air}

Kondisi terbaik didefinisikan sebagai kondisi perlakuan yang dapat memberikan hasil arang aktif terbaik, didasarkan atas rendemen dan daya serap yodium (Hartoyo et al., 1990). Untuk membuat arang aktif dari serbuk gergaji yang terbaik adalah dengan cara merendam arangnya dalam asam fosfat $5 \%$ dan diaktivasi pada suhu $900^{\circ} \mathrm{C}$ selama 30 menit (Tabel 5). Pada kondisi ini rendemen arang aktif yang dihasilkan sebesar $72,71 \%$, dan arang aktif mengandung kadar air 4,23\%, kadar zat terbang 5,84\%, kadar abu 42,53\%, kadar karbon terikat $52,25 \%$, daya serap terhadap kloroform $24,86 \%$, benzena $16,97 \%$ dan daya serap terhadap yodium sebesar $668,63 \mathrm{mg} / \mathrm{g}$. Nilai daya serap yodium yang diperoleh memenuhi syarat Standar Amerika dan dengan nilai sebesar itu maka produk arang aktif dapat digunakan untuk menjernihkan air (Anonim. 1978), namun perlu diperhatikan kandungan abunya yang relatif tinggi.

\section{Kualitas Minyak Goreng Bekas yang Dijernihkan}

\section{Asam lemak bebas}

Kandungan asam lemak bebas minyak goreng bekas setelah dijernihkan dengan arang aktif yang memiliki nilai daya serap yodium tertinggi $(668,8 \mathrm{mg} / \mathrm{g})$ mengalami penurunan dari $0,27 \%$ menjadi $0,17 \%$ atau mengalami penurunan sebesar $37,03 \%$. Hal ini menunjukkan bahwa arang aktif yang ditambahkan sebanyak 2,5 gram ke dalam minyak goreng bekas 100 $\mathrm{ml}$ dapat menyerap asam lemak bebas yang terbentuk oleh proses hidrolisa dan oksidasi yang dipercepat oleh pemanasan pada suhu tinggi. Kadar asam lemak bebas ini memenuhi persyaratan Standar Indonesia (SNI. 1987) karena kadarnya kurang dari 0,3\%. Namun demikian apabila dibandingkan dengan kandungan asam lemak bebas dari minyak goreng sebelum digunakan kadarnya masih lebih tinggi yaitu sebesar $0,09 \%$.

\section{Bilangan peroksida}

Bilangan peroksida minyak goreng bekas setelah dijernihkan dengan arang aktif mengalami penurunan dari 18,87 meq $\mathrm{O}_{2} / \mathrm{kg}$ menjadi $10,96 \mathrm{meq} \mathrm{O}_{2} / \mathrm{kg}$ atau mengalami penurunan sebesar 41,92\%. Hal ini menunjukkan bahwa arang aktif yang ditambahkan ke dalam minyak goreng bekas selain dapat menyerap senyawa yang merupakan hasil samping 
Tabel 5. Kondisi yang digunakan dalam pembuatan arang aktif Table 5. The used condition to manufacture activated charcoal

\begin{tabular}{|c|c|c|c|c|c|}
\hline \multicolumn{6}{|c|}{ Kondisi perlakuan arang aktif (The condition of activated charcoal treatment)* } \\
\hline 1 & 2 & 3 & 4 & 5 & 6 \\
\hline \multirow[t]{9}{*}{5} & 800 & 30 & 77,12 & 624,30 & 481,46 \\
\hline & & 60 & 67,24 & 521,12 & 350,40 \\
\hline & & 90 & 66,74 & 537,35 & 358,62 \\
\hline & 850 & 30 & 84,46 & 488,86 & 412,89 \\
\hline & & 60 & 70,92 & 363,59 & 257,85 \\
\hline & & 90 & 58,54 & 533,85 & 294,34 \\
\hline & 900 & 30 & 72,71 & 668,63 & 486,16 \\
\hline & & 60 & 54,95 & 571,38 & 313,97 \\
\hline & & 90 & 50,44 & 479,84 & 251,11 \\
\hline \multirow[t]{9}{*}{10} & 800 & 30 & 97,36 & 403,89 & 393,22 \\
\hline & & 60 & 84,59 & 403,41 & 341,24 \\
\hline & & 90 & 80,54 & 553,27 & 445,60 \\
\hline & 850 & 30 & 92,74 & 492,32 & 456,57 \\
\hline & & 60 & 78,09 & 440,72 & 344,15 \\
\hline & & 90 & 80,41 & 457,05 & 367,51 \\
\hline & 900 & 30 & 72,78 & 496,15 & 361,09 \\
\hline & & 60 & 64,36 & 492,33 & 316,86 \\
\hline & & 90 & 46,51 & 438,29 & 203,84 \\
\hline
\end{tabular}

Keterangan $\left(\right.$ Remarks) ${ }^{*}: 1=\left[\mathrm{H}_{3} \mathrm{PO}_{4}\right) ; 2=$ Suhu aktivasi $\left(\right.$ Activation temperature), ${ }^{\mathrm{O}} \mathrm{C} ; 3=$ Waktu aktivasi (Activation time), minutes; $4=$ Rendemen (Yield), \%; $5=$ Daya serap yodium (Adsorptive capacity of iodine), $\mathrm{mg} / \mathrm{g} ; 6=$ Kondisi terbaik untuk pembuatan arang aktif (The best condition to produce activated charcoal)

dari proses oksidasi minyak seperti keton, aldehida dan asam yang bersifat polar juga dapat melepaskan oksigen yang terikat pada ikatan rangkap di dalam minyak sehingga tidak terbentuk peroksida yang dapat menimbulkan bau tengik dan aroma yang tidak diinginkan, karena arang aktif yang dihasilkan bersifat lebih polar. Apabila dibandingkan dengan bilangan peroksida dari minyak goreng awal maka bilangan peroksidanya tidak berbeda jauh yaitu sebesar 10,94 meq $\mathrm{O}_{2} / \mathrm{kg}$.

\section{Kecerahan}

Kecerahan minyak goreng bekas setelah dijernihkan dengan arang aktif mengalami peningkatan dari 13,98\% menjadi 16,02\%. Hal ini menunjukkan bahwa arang aktif dapat menyerap warna minyak goreng bekas yang diakibatkan oleh proses oksidasi maupun hidrolisis. Namun demikian apabila dibandingkan dengan kandungan asam lemak bebas dari minyak goreng yang belum digunakan ternyata kecerahannya masih lebih rendah yaitu sebesar $39,85 \%$. 
Arang aktif serbuk gergaji kayu ... (Gustan Pari, Dudi Tohir, Mahpudin \& Januar Ferry)

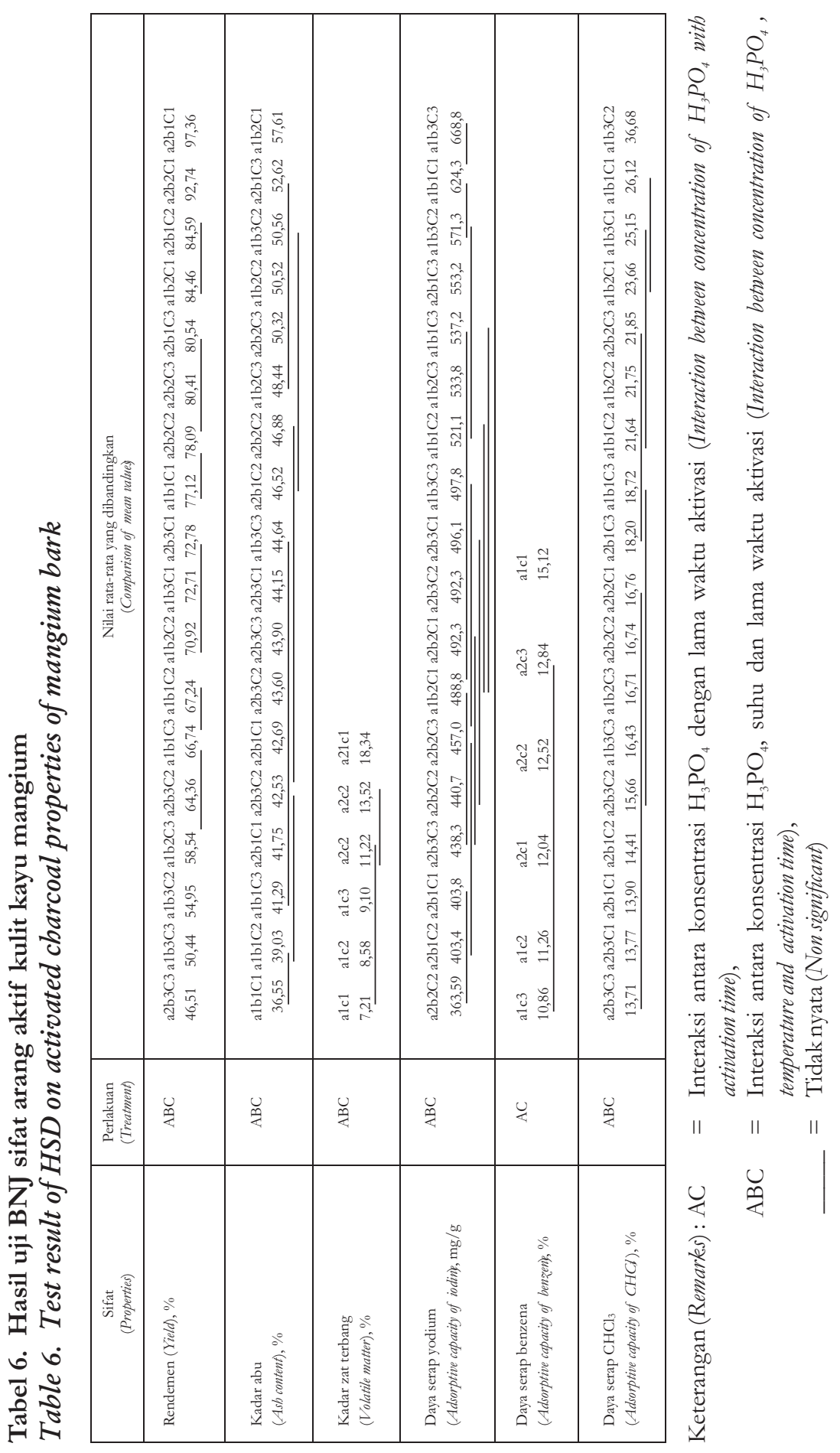




\section{KESIMPULAN}

Kualitas arang aktif serbuk gergaji yang terbaik sebagai adsorben diperoleh dari arang yang direndam asam fosfat $5 \%$ dan diaktivasi pada suhu $900^{\circ} \mathrm{C}$ selama 30 menit. Pada kondisi ini rendemen arang aktif yang dihasilkan sebesar $72,71 \%$, dan arang aktif serbuk gergaji kayu mengandung kadar air 4,23\%, kadar zat terbang 5,84\%, kadar abu 42,53\%, kadar karbon terikat 52,25\%, daya serap terhadap kloroform 24,86\%, benzena $16,97 \%$ dan daya serap terhadap iodin sebesar $668,63 \mathrm{mg} / \mathrm{g}$. Arang aktif yang dihasilkan lebih bersifat polar, sehingga dapat digunakan untuk menyerap polutan yang bersifat polar seperti aldehida dan alkohol.

Kualitas minyak goreng bekas menjadi lebih baik setelah dijernihkan dengan arang aktif yang ditandai dengan menurunnya kandungan asam lemak bebas dari 0,27\% menjadi 0,17\% dan bilangan peroksida dari 18,87 menjadi 10,96 meq $\mathrm{O}_{2} / \mathrm{kg}$, serta meningkatnya kecerahan warna dari $13,98 \%$ menjadi $16,02 \%$.

\section{DAFTAR PUSTAKA}

Anonim. 1978. American water works association B 600-78. Colorado.

. 1987. Mutu dan cara uji minyak sawit. Standar Nasional Indonesia (SNI) 01001301987. Dewan Standardisasi, Jakarta.

. 1995. Arang aktif teknis. Standar Nasional Indonesia (SNI) 06-3730-1995. Dewan Standardisasi, Jakarta.

Hartoyo, Hudaya \& Fadli 1990. Pembuatan arang aktif dari tempurung kelapa dan kayu bakau dengan cara aktivasi uap. Jurnal Penelitian Hasil Hutan, 8 (1): 8-16. Pusat Penelitian dan Pengembangan Hasil Hutan, Bogor.

Pari, G., Nurhayati, T \& Hartoyo. 2000. Kemungkinan pemanfaatan arang aktif kulit kayu Acacia mangium WILLD untuk pemurnian minyak kelapa sawit. Buletin Penelitian Hasil Hutan, 18 (1): 40-53. Pusat Penelitian dan Pengembangan Hasil Hutan, Bogor.

Pari, G. 2004. Kajian struktur arang aktif dari serbuk gergaji kayu sebagai adsorben emisi formaldehida kayu lapis. Disertasi. Sekolah Pascasarjana, Insitut Pertanian Bogor. Tidak diterbitkan.

Perkins, E.G. 1960. Nutritional and chemical changes occuring in heated fats: a review. Food Technol. 14: 509

Sudjana. 1980. Disain dan analisis eksperimen. Tarsito, Bandung.

Sudradjat dan S. Soleh. 1994. Petunjuk teknis pembuatan arang aktif. Puslitbang Hasil Hutan dan Sosial Ekonomi Kehutanan, Bogor.

Winarno, F.G. 1997. Kimia Pangan dan Gizi. PT Gramedia, Jakarta. 